AperTO - Archivio Istituzionale Open Access dell'Università di Torino

\title{
Effectiveness of mechanical weed control on Italian flint varieties of maize
}

\section{This is the author's manuscript}

Original Citation:

Availability:

This version is available http://hdl.handle.net/2318/1658817

since 2020-07-23T09:20:22Z

Published version:

DOI: $10.1017 / S 1742170517000813$

Terms of use:

Open Access

Anyone can freely access the full text of works made available as "Open Access". Works made available under a Creative Commons license can be used according to the terms and conditions of said license. Use of all other works requires consent of the right holder (author or publisher) if not exempted from copyright protection by the applicable law. 


\section{IIIS AperTO}

UNIVERSITÀ

DEGLI STUDI

DI TORINO

This is the author's final version of the contribution published as:

Fogliatto S., Milan M., De Palo F., Ferrero A., Vidotto F., Effectiveness of mechanical weed control on Italian flint varieties of maize, Renewable Agriculture and Food Systems, 2018, pagg. XX-XX, DOI

The publisher's version is available at:

https://www.cambridge.org/core/journals/renewable-agriculture-and-food-systems

When citing, please refer to the published version.

Link to this full text:

http://hdl.handle.net/2318/1658817 


\section{Effectiveness of mechanical weed control on Italian flint varieties of maize}

Silvia Fogliatto, Marco Milan, Fernando De Palo, Aldo Ferrero and Francesco Vidotto

Dipartimento di Scienze Agrarie, Forestali e Alimentari-Università degli Studi di Torino

Largo Paolo Braccini, 2 - 10095 Grugliasco (TO) Italy

Corresponding author: silvia.fogliatto@unito.it

\section{Abstract}

Weed control is one of the most important practices for a satisfying crop performance. In organic farming, weeds are mainly controlled by using mechanical methods, which may result in incomplete crop selectivity. Maize is one of the crops for which mechanical weed control is commonly applied. To assess weed control efficacy and the possible crop injuries caused by mechanical interventions (harrowing, hoeing and ridging), a field experiment was carried out in 2013-2014 on traditional flint Italian varieties of maize (Marano, Ottofile, Pignoletto, Nostrano and the hybrid Maranello) suited for organic food production. The study included the following treatments: weed control with a spring tine harrow (STH), manual weed removal all season long (MWR), spring tine harrowing + manual weed removal (STH+MWR) and an untreated check (CHK). In the two years, the experiment was carried out in two similar fields in which 60 plots $\left(6^{\star} 10 \mathrm{~m}\right)$ were arranged in a RCBD with three replications. Weed control efficacy was assessed by determining weed density, weed species composition and weed cover after each mechanical intervention in the STH and CHK plots. Weed diversity indices were also calculated at the final assessment. The possible crop injuries caused by mechanical means were assessed by determining maize plant height, number of leaves, and plant density after each mechanical intervention. At maturity, maize yield and other yield-related traits (1000-seed weight, hectolitre weight, and grain moisture) were determined. The results showed that 
1 the mechanical treatments lowered the weed infestation, without changing weed species

dominance and richness; even though they were not able to completely control the weeds. In both years, the final weed density in STH plots was of about 50 plants $\mathrm{m}^{-2}$. Better weed control was obtained when weeds were at early growth stages and with a repeated number of harrowings. Mechanical weeding did not cause significant injury in terms of plant height nor density; however, for Marano and Maranello, a delay in the crop cycle was observed as shown by the lower number of leaves in STH compared to MWR. Yield ranged from $0.3 \mathrm{t} \mathrm{ha}^{-1}$ for Marano $\mathrm{CHK}$ to $10.4 \mathrm{t} \mathrm{ha}^{-1}$ for the hybrid Maranello in $M W R+S T H$. Yield and yield-related traits were not affected by mechanical weeding.

Keywords: weeds, spring-tine harrowing, maize yield, organic farming, crop injury

\section{Introduction}

Mechanical means are some of the most common methods used to control weeds in crops as they can be applied at different times of the cropping cycle: in pre-planting during the seedbed preparation to stimulate weed seed germination, as in the case of the false seedbed technique, and after crop emergence to eliminate the weeds (Bond, 2007; Meissle et al., 2009). Mechanical control methods can be adopted, in combination with herbicides, in integrated weed management programs. In Europe, Integrated Weed Management (IWM) is considered part of the Integrated Pest Management (IPM), and its application has become mandatory in all European Union Member States following the adoption of the Sustainable Use of Pesticides Directive (2009/128/EC) of the European Commission (Moss, 2010). In this view, herbicide use can be reduced and partially replaced by alternative control methods. In maize, for example, herbicide use can be lowered to $60 \%$ when integrated with mechanical tillage in a rotational cropping system (Pimentel et al., 1991). In sustainable agriculture, the use of mechanical weed control has a great importance as it presents less risks of harming the environment, it may prevent the 
1 selection of herbicide resistant populations in weeds and it is safer for the operators (Abdin

et al., 2000; Upadhyaya and Blackshaw, 2007a). In organic cropping systems weeds are one of the major issues that need to be addressed appropriately in order to get a satisfying crop performance (Bàrberi, 2002; Upadhyaya and Blackshaw, 2007b). In such cultivation systems, specific regulations limit the range of weed control techniques available to preventive methods (e.g. crop rotation, false seed bed) and direct physical and mechanical methods (i.e. flame weeding, spring tine harrowing) (Vidotto et al., 2007). Even in this type of agriculture mechanical means are the most commonly adopted methods for weed control (Armengot et al., 2013; Melander, 2014).

Direct mechanical means, harrowing in particular, applied in established crops act mainly by weed seedling burial and uprooting (Cloutier et al., 2007). Both factors are responsible for weed control even though the prevalent mechanism has yet to be determined (Cirujeda et al., 2003). In fact, some previous studies found that burial was the principal factor, while other studies showed that uprooting is fundamental for the final control of the weeds, especially at the first growth stages (Fogelberg and Gustavsson, 1998; Kurstjens and Kropff, 2001). The efficacy of mechanical means used to control weeds is strictly dependent on many factors that are not always easily manageable by the farmers. Unfavourable weather and soil conditions at the moment of the tillage may delay cultivations, affecting weed control (Duerinckx et al., 2005). Wet soil conditions due to prolonged rains may lead to a fast weed growth and poor weed control because grown-up weeds are not well controlled by mechanical means. On the contrary, crusty or hard clayey soils occasionally need a proper mechanical tillage in order to break the crust and loose the clumps prior to the weed control operations (Kouwenhoven, 1997). Weed stage can also affect the effectiveness of the mechanical means; in general, their application results in a better weed control at the earliest weed growth stages, while the crop should be at a later stage (Kouwenhoven, 1997). The best weed growth stage to perform cultivations also 
1 depends on the mechanical means chosen and the machinery adjustment set by the 1 operators (Van der Weide et al., 2008).

The effects of the uncontrollable factors, namely soil and weather conditions and weed stage, could be managed through regulations of the operative technique such as the number of passages and the working speed. Cultivation frequency and forward speed are strictly related to weed density and weed species compositions (Laguë and Khelifi, 2001).

Weed harrowing, hoeing and ridging are some of the most common mechanical means adopted in row-planted crops for weeding. Harrowing and hoeing are effective between crop rows but not in the intra-rows; for this reason, other practices such as ridging could help in controlling intra-row infestations (Cirujeda et al., 2003).

Mechanical interventions may result in poor selectivity causing significant crop injuries when treating the whole crop both in broadcast and row-planted crops. In general, the more effective the mechanical weed control, the less selective for the crop (Rasmussen et al., 2008). For example, high driving speed, deep penetration of the working tools and thick tines are the best setting for efficient weed control in contrast to low working speed, thin tines and their vertical orientation which can assure crop selectivity (Duerinckx et al., 2005). As a consequence, cultivation techniques need to be balanced in order to get a satisfying weed control and crop selectivity. Crop damage can be caused by the direct contact with working implements, or indirectly by soil covering, which both may result in yield reduction.

Maize is one of the crops for which mechanical weed control is commonly applied even in combination with herbicides. Italy is one of the largest European maize producers with about 995,000 hectares (Istituto Nazionale di Statistica (ISTAT), 2016). Moreover, Italy has also the largest area of organic maize production in Europe, with more than $1 \%$ of the overall Italian maize area (Ceddia and Cerezo, 2008), in which mechanical means are predominantly adopted. 
1 Maize can tolerate early weed infestations for the firsts 2-6 weeks after planting without

significant yield losses; however, this range of tolerance and the possible damage can vary according to weed density, weed species, time of weed and maize emergence and the environmental conditions (Cloutier et al., 2007).

The objective of the present study was to assess weed control efficacy and the possible crop injuries caused by mechanical interventions (harrowing, hoeing and ridging) in traditional flint Italian varieties of maize during two cropping seasons (2013-2014).

\section{Materials and Methods}

The study was carried out at the experimental station of the Dipartimento di Scienze Agrarie, Forestali e Alimentari of the University of Turin, during two cropping seasons (2013-2014). The experimental station is located in northwest Italy in an area traditionally cultivated with maize, characterized by sandy-loam soil.

The following five traditional flint Italian varieties of maize for human consumption were considered in the study: Marano, Ottofile, Pignoletto, Nostrano and the hybrid Maranello.

These varieties were chosen among those most commonly cultivated in North Italy before the introduction of hybrids. These varieties were also considered interesting in organic agriculture on the basis of a previous experiment conducted in Piemonte (Spagnolo et al., 2005). The seeds of the varieties were provided by the Bergamo Section of the Istituto Sperimentale per la Cerealicoltura (Italy), which maintains a collection of the Italian varieties of maize.

The experimental field was mouldboard ploughed during the autumn before each year to a depth of $25 \mathrm{~cm}$ and harrowed about a month before seeding to prepare the seedbed. The day preceding maize sowing, the plot was again harrowed to eliminate all the newly emerged weeds. Maize seeds were sown in two different fields on May $4^{\text {th }}$ and April $19^{\text {th }}$ in 2013, and 2014, respectively, using a two-row trailed Gaspardo planter (model SP510, 
1 Pordenone, Italy). Spacing between the rows was $75 \mathrm{~cm}$ and $21 \mathrm{~cm}$ between the seeds, 1

with initial density of 6.3 plants $\mathrm{m}^{-2}$.

During the cropping seasons, maize irrigation was carried out once per year, giving about 70-80 $\mathrm{mm}$ for the whole plot. Rainfalls covered the remaining crop water needs.

Maize fertilization was provided each year with Urea $\left(150 \mathrm{~kg} \mathrm{ha}^{-1}\right)$ before ridging.

\section{Mechanical interventions}

Direct weed control treatments were performed at the crop post-emergence stage and named:

- STH: spring tine harrowing at different growth stages followed by inter-row hoeing and hoe ridging;

- MWR: manual weed removal with hand-hoe all season long to exclude competition from weeds;

- STH+MWR: as treatment STH but supplemented with manual removal;

- CHK: untreated.

The number of passes with mechanical means in the STH and STH+MWR plots varied each year in order to simulate a real situation in which farmers varied the number of treatments to obtain a good weed control in relation to the climatic conditions and the field infestation. In particular, in 2013 two interventions with a spring tine harrow at 17 and 26 days after sowing (DAS), corresponding to 2-3 and 4-5 leaf stage respectively, were carried out and in 2014 three interventions were performed at 20, 26 and 35 DAS. Subsequently, every year a passage with a hoeing-ridging machine (at 9-10 leaf stage, about 40 DAS) was performed in the STH and STH+MWR treatments.

Weed harrowing was carried out with a $2.5-\mathrm{m}$ wide spring tine harrow with 48 elastic tines; driving speed was maintained from 5 to $7 \mathrm{~km} \mathrm{~h}^{-1}$ and the tine angle was reduced and 
1 adjusted on the basis of visual assessments of the crop soil cover to provide an 1

appropriate treatment.

In 2013, MWR was carried out four times during the growing season, while in 2014 six interventions were necessary to eliminate the weeds because of the higher infestation.

\section{Experimental design}

The experiment was arranged in a randomised complete block design with three replications. Plots were 6 meters ( 8 maize rows) wide by $10 \mathrm{~m}$ long, for a total of 60 plots, resulting from 20 different combinations of maize varieties (5) and weed control treatments (4). In the two years, the experiment was carried out in two similar fields close each other, in order to avoid carryover weed infestations.

\section{Weed assessment}

Weed data in terms of weed specie composition, density and cover were collected about a week after each mechanical intervention in the STH and CHK plots. In particular, weeds were counted in a squared frame of $0.5 \times 0.5 \mathrm{~m}$ randomly placed between crop rows, including both interrow and intrarow areas. No weed counting was carried out on MWR and STH+MWR plots because they were maintained weed free all season long.

Weed diversity indices were also calculated for STH and $\mathrm{CHK}$ plots at the last weed assessment, after all the mechanical intervention, separately for each year, in order to assess if weed species diversity and dominance changed as a consequence of the mechanical treatments. In particular, dominance index of Simpson (D) was determined as follows:

$$
D=\sum\left[\frac{p i}{N}\right]^{2}
$$


1 and Shannon diversity index $\left(\mathrm{H}^{\prime}\right)$ was calculated as follows:

$$
H^{\prime}=\sum\left(-\frac{p i}{N}\right) \ln \left(\frac{p i}{N}\right)
$$

where $p i$ is the density of the $\mathrm{i}^{\text {th }}$ species, $N$ is the total weed density of all the species (Clements et al., 1994).

\section{Crop assessment}

The possible crop damages caused by mechanical weeding were estimated by determining several maize growth and yield parameters. Maize plant height, number of leaves, and plant density were determined within few days after each mechanical weeding. In both years, a total of four assessments were performed. In 2013, both the third and fourth assessment were carried out after the last mechanical weeding.

At maturity, maize yield and other yield-related traits (1000-seed weight, hectolitre weight, grain moisture) were determined by hand harvesting an area of about $15 \mathrm{~m}^{2}$ for each plot (2 adjacent central maize rows, each $10 \mathrm{~m}$ long). Afterwards, the remaining area of the plots was combined.

\section{Statistical analyses}

The effect of the maize variety, the year, the mechanical treatments and their interactions on weed density were assessed using the GLM Analysis of Variance procedure of the statistical package SPSS (version 23). The efficacy of each STH treatment in each year was evaluated by comparing weed density between $\mathrm{CHK}$ and STH trough another ANOVA analysis $(P \leq 0.05)$. REGWF post-hoc test was used to find out differences among the compared values. 
1 For the crop assessments, ANOVA analysis and post-hoc test were performed to compare 1

the values recorded at the same assessment: plant height, number of leaves, and plant density between maize varieties, separately per year. Moreover, the same analyses were carried out to compare the crop values among treatments at each assessment and for each variety. Yield and yield-related traits were compared to find out differences among the treatments within variety, differences among varieties averaging the treatments and differences among the treatments averaging for the varieties.

\section{Results and Discussion}

Weed assessment

The ANOVA analysis conducted on weed density showed a significant effect of the year and of the treatments while no differences among varieties were found; the interactions among the main factors were also non-significant (data not shown).

Initial weed infestation in 2013 and 2014 differed, being higher in 2014 (304 plants $\mathrm{m}^{-2}$ ) compared to 2013 (163 plants $\mathrm{m}^{-2}$ ) (Table 1$)$. Plots that underwent mechanical treatments always showed a significant lower weed density compared to the CHK plots. Higher efficacy of the first two STH interventions was recorded in 2013 with values of weed reduction exceeding $50 \%$ between STH and $\mathrm{CHK}$ plots, while weed density was reduced by only about $30 \%$ in 2014 . The higher efficacy recorded in 2013 may be due both to a lower initial weed density and weeds being at early growth stage as demonstrated by the lower values of weed cover over the soil surface. This was already established by previous studies in which the highest efficacy obtained by mechanical means, in particular by harrowing, occurred when weeds were at early growth stages (e.g. cotyledon stage) (Lundkvist, 2009; Kolb and Gallandt, 2012). The lower weed density at the moment of the treatment is another factor contributing to the efficacy of the mechanical treatment, as demonstrated by Kouwenhoven (1997). Moreover, the prevalence of certain weed species, 
1 their density and their growth stage, has been demonstrated by previous study to affect 1

the efficacy of weed harrowing (Kurstjens and Kropff, 2001).

At the third STH treatment a higher weed reduction was instead recorded in 2014 even though the weed density remained higher than in 2013. In 2014, a total of four STH treatments ( 3 passes with spring-tine harrow +1 pass with hoeing-ridging machine) have been necessary to obtain the same weed density level (about 50 plants $\mathrm{m}^{-2}$ ) of that recorded in 2013 , when a total of three STH treatments were performed (2 passes with spring-tine harrow +1 pass with hoeing-ridging machine). However, the final percentage of soil covered by weeds in 2014 was lower than that of the previous year, demonstrating that a further mechanical treatment could also help maintaining weeds at the initial growth stages. Repeated harrowing has been reported to better control weeds in spring barley and in winter wheat even though increasing the number of passages caused a decrease in crop yield (Melander et al., 2005; Ulber et al., 2009). Thus, the appropriate number of harrowing passages should be that able to maximize weed control without damaging or reducing the crop yield. In both years, the efficacy of mechanical weeding was only partial as the final weed density was of about 50 plants $\mathrm{m}^{-2}$; this partial effectiveness could lead to yield reduction in the short term, but could also worsen the infestation level in the long term as non-controlled weeds may reach maturity and set seeds, contributing to soil seed bank enrichment (José-María and Sans, 2011; Armengot et al., 2013).

In both years, the most prevalent weed was Chenopodium album both in CHK and STH treatments (Figure 1). In 2013, the weed species present in the two considered treatments were basically the same and with a similar abundance; only, Panicum dichotomiflorum and C. album were slightly less represented in STH, while Solanum nigrum and Echinochloa crus-galli were more present. In 2014 , as in the previous year, the recorded species were similar in $\mathrm{CHK}$ and $\mathrm{STH}$, with again S. nigrum and E. crus-galli having higher densities in 
1 STH. These two species were the most abundant in STH treatments in both years 1

probably because were those less controlled by mechanical treatments.

Comparing the two years, the infestation slightly changed likely because the trials were hosted in two different fields, with a different soil seed bank composition, even if adjacent. In particular, in 2013 Portulaca oleracea represented almost $30 \%$ of all the weed individuals while in 2014 it counted for less than $1 \%$.

In general, the most represented weed species in these fields, C. album and E. crus-galli, were those commonly observed in Italian maize fields as reported in a previous survey (Vidotto et al., 2016). Weed species found in the treatments CHK and STH, showed a similar presence; this was also confirmed by the two diversity indices, Simpson and Shannon, which showed a similar weed species dominance and diversity (Figure 1). In particular, Simpson indices were similar between both $\mathrm{CHK}$ and STH and years with values of about 0.35 , indicating an absence of dominance of few species. Similar Shannon indices were recorded for CHK and STH plots with values of about 1.34 in 2013 and 1.4 in 2014 (Figure 1), suggesting a similar weed diversity between treatments and years.

According to these results, it is possible to confirm what already observed in a previous study, which found that harrowing did not cause a change in species dominance and richness and thus maintained the weed diversity (Armengot et al., 2013).

The compared treatments were also quite similar in terms of number of species found; in particular, 17 species were counted in CHK and 11 in STH plots in 2013 (data not shown). In 2014, a total of 11 species were observed in CHK and 7 species in STH plots. The number of species found in STH and CHK plots, as well as the Shannon diversity indices, fall within the range of that observed in a previous study carried out in maize fields in Northern Italy, in which the number of species varied from 5 , in plots sprayed with herbicides both in pre-and post-emergence and hoed, to 16 species, in plots sprayed with herbicides in post-emergence only and also hoed (Vasileiadis et al., 2015). 
22

3

74

5

\section{Crop assessments}

Plant height

In both years, ANOVA results indicated that the effect of the applied mechanical treatments was not significant (data not shown). In 2013, a significant effect of the variety on plant height (averaging among treatments) was detected only at the final assessment, while in 2014 differences among varieties were always found with the exception of the third assessment (Table 2). In particular, Nostrano was the tallest variety at both years, with values higher than $70 \mathrm{~cm}$ after the last mechanical weeding. The shortest varieties were Pignoletto in 2013 and Maranello, the hybrid variety, in 2014. Taller plants are usually more susceptible to damage by mechanical treatments; this has been demonstrated in different crop species, such as barley (Rasmussen et al., 2004). Thus, among the studied varieties, Nostrano could be the most affected one due to its tallness. Weed and crop traits measures are usually carried out to assess the efficacy of the mechanical methods of weed control and the susceptibility of the crop, respectively; plant height could be one of the crop traits that could be considered (Kurstjens et al., 2004; Vanhala et al., 2004). Moreover, maize height has been demonstrated to be positively correlated with yield (Sowinski et al., 2002).

\section{Number of leaves}

The comparison among the mechanical treatments for all the varieties, with the only exception of Pignoletto, showed significant differences only at the final assessment in which the untreated check had always a lower number of leaves (Table 3). Generally, the applied mechanical treatments had a similar effect on the number of leaves across varieties; however, for Marano, in particular in 2014, STH treatment showed the same number of leaves of that recorded for $\mathrm{CHK}$ and STH+MWR suggesting a partial negative 
1 effect caused by the mechanical treatments. Maranello in 2014 also showed a lower

number of leaves in STH compared to MWR and STH+MWR but this was probably due to the scarce efficacy of the weeding treatment. Considering the number of leaves per plant in each variety, averaging among treatments, Maranello and Marano showed the lowest values, while Nostrano and Pignoletto the highest, in particular at the first and fourth assessment.

Leaf number is a varietal characteristic but can also indicate, as in this experiment, the growth stage reached by the maize varieties. Mechanical weeding can cause injuries to maize by delaying the growth or by damaging the leaves which both may result in a lower number of leaves. Previous studies have found that harrowing performed on maize at twoleaf stage can cause injury if the driving speed exceeds 3-4 km per hour (Van der Weide et al., 2008). The higher driving speed used in this experiment (about $7 \mathrm{~km} / \mathrm{h}$ ) could be the reason of the lower number of leaves found in Marano. Moreover, the incomplete weed control obtained with the mechanical treatments can further contribute to lower the leaf number. In addition, Hall et al. (1992) showed that the longevity of maize lower leaves was reduced by the competition with weeds for light and nutrient, resulting in a high number of senescent leaves.

\section{Maize density}

In both years, no differences on plant density were found among the treatments, while the only significant differences were those among varieties, averaging among treatments (Table 4).

In 2013, the hybrid variety Maranello showed a higher plant density, followed by Ottofile. In the same year, Marano and Nostrano had a lower density than the other varieties in two assessments. However, in 2014 the density was generally higher for all the varieties and differences were only found at the third assessment, with again Maranello having the 
1 highest density and Pignoletto the lowest. These differences were however not significant

in the last assessments.

Maize density was used as an indicator of the selectivity of the mechanical weeding as plant uprooting can occur during the treatment (Kurstjens et al., 2000; Pannacci and Tei, 2014). Maize harrowing demonstrated in this study to be selective as no damages occurred to the plants, confirming what found in previous studies for summer annual crops (Pannacci and Tei, 2014). Maize density in this study averaged from 4 to 6 plants $\mathrm{m}^{-2}$; high plant density has been demonstrated, for maize and other crops, to favour crop selectivity of the mechanical means as close plants on the rows may move away the tines avoiding crop injuries (Melander et al., 2005). Moreover, high plant density is able to limit the weed biomass (Sanyal et al., 2008); a study found that the increase of maize density from 4 to 10 plants $\mathrm{m}^{-2}$ permitted a weed biomass reduction higher than $50 \%$ (Tollenaar et al., 1994). In our study, Maranello which was the variety that had the highest plant density was also the one less infested and thus probably the most competitive.

\section{Maize yield}

In both years, for all the tested varieties the untreated check showed significant lower yields compared to the mechanical treatments, with values ranging from $0.3 \mathrm{t} \mathrm{ha}^{-1}$ for Nostrano in 2013 to $4 \mathrm{t} \mathrm{ha}^{-1}$ for Maranello in 2014 (Figure 2).

In general, STH showed intermediate yield values among $\mathrm{CHK}$ and the other two treatments, MWR and MWR+STH. Marano was the least productive variety while Maranello, being hybrid, the most productive one as the yield ranged from $0.3 \mathrm{t} \mathrm{ha}^{-1}$ for Marano $\mathrm{CHK}$ to $10.4 \mathrm{t} \mathrm{ha}^{-1}$ for Maranello MWR+STH. This study highlighted that, besides the hybrid variety Maranello, Pignoletto showed the highest yield, which peaked at about 6 $t$ ha-1. This result was in agreement with a previous study conducted in Italy on old vitreous maize varieties cultivated organically, in which Pignoletto demonstrated to be the most 
1 productive one, the most rapid to grow, with high competitive ability towards weeds and 1

thus the old maize variety most suitable to grown organically (Spagnolo et al., 2005).

As for the majority of the tested varieties mechanical treatments and manual weed removal did not show significant yield differences, it was possible to observe that the mechanical treatments did not cause significant yield losses due to plant damages. In particular, this was more detectable for two varieties, Nostrano and Ottofile. In fact, Nostrano at both years and Ottofile in 2014 showed similar yields between MWR+STH and MWR and thus the presence of some damages caused by STH can be excluded; in addition, STH yield was significantly lower than MWR+STH indicating that the lower productivity was probably due to an incomplete weed control of the mechanical means and not to a plant damage. This conclusion was also drawn by previous studies in which lower crop yields were obtained in fields with mechanical weed control, compared to chemical control, mainly because of the poor weed control as no or very few damages occurred after the weeding operations (Mulder and Doll, 1993; Gilbert et al., 2009). Moreover, yield reductions can also be caused by other factors as enhanced leaf disease that can result from a higher availability of nitrogen as a consequence of an enhanced nitrogen mineralization following mechanical weeding (Steinmann, 2002).

\section{Other yield-related traits}

1,000 seed weight. In our study, Marano was the variety that in both years recorded the lowest 1,000 seed weight, with an average of $200 \mathrm{~g}$ (Figure 2). The highest values were instead recorded for Maranello and Ottofile, with weight that exceeded $300 \mathrm{~g}$. With exception of Marannello in both years, Marano in 2013 and Ottofile in 2013, no significant differences were found among treatments, even though higher values of 1,000 seed weight were usually found in MWR and MWR+STH treatments. In general, CHK had similar or lower 1,000 weight values than the other treatments. Significantly lower grain 
1 weights were observed in CHK for Maranello (in both years) and Ottofile (in 2013 only), as 1

in previous study conducted on maize in Brazil, in which lower grain weights were obtained in non-weeded plots (Silva et al., 2010). In the same study, no differences were found between mechanical treated plots neither with different moment of treatment nor with increasing number of weeding operations (Silva et al., 2010).

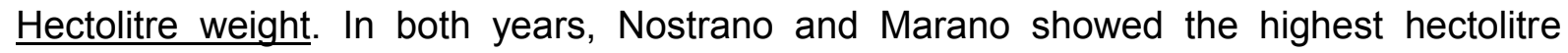
weight with about $70 \mathrm{~kg} \mathrm{hl}^{-1}$, while Maranello and Ottofile had the lowest values. Regarding the effect of mechanical weeding on the hectolitre weight, no big differences were detected among the treatments. Only Pignoletto showed differences among the treatments in both years, however with opposite results; in particular, in 2013 the CHK had significant higher hectolitre weight, while in $2014 \mathrm{CHK}$ was the lowest with MWR and MWR+STH reaching the highest values. Hectolitre weight, as well as 1,000 seed weight, is one of the measures of maize quality and it is correlated with good milling performance (Tolera et al., 1998; Engelbrecht, 2008); in our study, Marano was the least productive variety and showed the highest hectolitre weight, while Maranello was the most productive but presented a low hectolitre weight. It should be noted that these two varieties showed an opposite trend regarding 1,000 seed weight. Controversial results are reported in the literature about the presence or absence of correlation between 1,000 seed weight and hectolitre weight; however, despite the fact that some correlation may exist, these two quality indices are not alternative to estimate yield quality (Engelbrecht, 2008).

Maize grain moisture. In 2013, moisture values at harvest were generally high and ranged from about $17 \%$ up to more than $25 \%$, while in 2007 the moisture was lower with values averaging about $12-14 \%$ and thus near to the conservation moisture.

In 2013, averaging between varieties, no influence of the applied treatments was found, while in 2014 CHK showed the highest moisture values. In agreement with our results, a previous study conducted on maize showed that the mechanical treatment (rotary-hoeing) 
1 did not affect the grain moisture content (Begna et al., 2001). The higher moisture content 1

recorded in $\mathrm{CHK}$ in 2013 can be attributed to the weed presence as weed seeds can have been harvested with the grains and can have raised the maize moisture (Lyon et al., 2009). Marano in both years showed low moisture at harvest, while Maranello the highest, followed by Pignoletto (Figure 2). Within varieties, no big differences among the treatments were found; in particular, in 2013 Maranello showed a lower moisture for CHK, while in 2014 Ottofile recorded highest moisture in CHK. It has been demonstrated that in maize a high grain moisture content causes a decrease in hectolitre weight because humid kernels are bigger and a low number of kernels fits in the container used for the measure of the hectolitre weight (Engelbrecht, 2008). This was also confirmed in our study in which Marano, that had low moisture content, showed a high hectolitre weight, or by Maranello but with an opposite trend.

In this study, mechanical weeding significantly lowered weed density even though the efficacy of weed control was not sufficient to avoid yield losses. Higher weed control was obtained with weeds at early growth stages and with a repeated number of harrowing. The weed species composition was that typically observed in other spring crops and the mechanical interventions did not change species richness. Regarding the effect on maize plants, mechanical weeding did not cause significant injury in terms of plant height or density; however, for some varieties, i.e. Marano and Maranello, mechanical treatments caused a delay in the crop cycle as shown by the lower number of leaves in STH compared to MWR at the last assessment.

Neither yield nor yield-related traits were affected by mechanical weeding. Maize yield in STH was intermediate between that obtained in untreated and in MWR, and this result has to be attributed to the incomplete weed control as no damages were observed on the crop. Regarding the tested varieties, the study confirmed the superiority of the hybrid Maranello being the most productive, while among the traditional varieties Pignoletto showed the 
1 highest yield. Marano showed the lowest yield but with good quality as demonstrated by

22 the high hectolitre weight and the low grain moisture.

3 The results of this study confirmed that mechanical weeding can be an applicable practice 6

74 to control weeds both in organic and in conventional farming as an integrative means to ${ }_{0}^{9} 5$ limit weed infestation without causing crop injuries, even though alone is not able to control 11

126 the weeds effectively. Even though in organic farming, maize can be sold at higher price,

${ }_{15}^{14} 7$ usually $30 \%$ more than the conventional one, this cannot compensate the yield losses caused by the incomplete weed control obtained with the sole use of mechanical weeding (Piazza, 2004). Further studies are necessary to determine which mechanical operations and adjustments are the most effective in controlling weeds in different cropping conditions. 


\section{References}

Abdin, O. A., Zhou, X. M., Cloutier, D., Coulman, D. C., Faris, M. A., and Smith, D. L. 2000. Cover crops and interrow tillage for weed control in short season maize (Zea mays). European Journal of Agronomy 12(2):93-102.

Armengot, L., José-María, L., Chamorro, L., and Sans, F. X. 2013. Weed harrowing in organically grown cereal crops avoids yield losses without reducing weed diversity. Agronomy for Sustainable Development 33(2):405-411.

Bàrberi, P. 2002. Weed management in organic agriculture: are we addressing the right issues? Weed Research 42(3):177-193.

Begna, S. H., Hamilton, R. I., Dwyer, L. M., Stewart, D. W., Cloutier, D., Liu, A., and Smith, D. L. 2001. Response of corn hybrids differing in canopy architecture to chemical and mechanical (rotary hoeing) weed control: Morphology and yield. Journal of agronomy and crop science 186(3):167-173.

Bond, W. 2007. Non-Chemical Weed Management. In R. E. L. Naylor (ed.). Weed Management Handbook Ninth Edition. Published for the British Crop Protection Council by Blackwell Science, Oxford; Malden, MA. p. 280-301.

Ceddia, M. G. and Cerezo, E. R. 2008. A Descriptive Analysis of Conventional, Organic and GM Crop and Certified Seed Production in the EU. European Commission, Luxembourg.

Cirujeda, A., Melander, B., Rasmussen, K., and Rasmussen, I. A. er. 2003. Relationship between speed, soil movement into the cereal row and intra-row weed control efficacy by weed harrowing. Weed research 43(4):285-296.

Clements, D. R., Weise, S. F., and Swanton, C. J. 1994. Integrated weed management and weed species diversity. Phytoprotection 75(1):1-18. 
1 Cloutier, D., Van Der Weide, R. Y., Peruzzi, A., and Leblanc, M. L. 2007. Mechanical weed management. In M. K. Upadhaya and R. E. Blackshaw (eds.). Non-chemical weed management: principles, concepts and technology $\mathrm{CABI}$, Wallingford, UK.

Duerinckx, K., Mouazen, A. M., Anthonis, J., and Ramon, H. 2005. Effects of Springtine Settings and Operational Conditions on the Mechanical Performance of a Weed Harrow Tine. Biosystems Engineering 91(1):21-34.

Engelbrecht, M. L. 2008. Assessment of variance in measurement of hectolitre mass of wheat and maize, using equipment from different grain producing and exporting countries. Msc thesis, University of Stellenbosch.

Fogelberg and Gustavsson. 1998. Resistance against uprooting in carrots (Daucus carota) and annual weeds: a basis for selective mechanical weed control. Weed Research 38(3):183-190.

Gilbert, P.-A., Vanasse, A., and Angers, D. A. 2009. Harrowing for weed control: Impacts on mineral nitrogen dynamics, soil aggregation and wheat production. Soil and Tillage Research 103(2):373-380.

Hall, M. R., Swanton, C. J., and Anderson, G. W. 1992. The Critical Period of Weed Control in Grain Corn (Zea mays). Weed Science 40(3):441-447.

Istituto Nazionale di Statistica (ISTAT). 2016. Italia in cifre 2016. www.istat.it [Internet]. Available at Website http://www.istat.it/it/files/2016/12/ItaliaCifre2016.pdf.

José-María, L. and Sans, F. X. 2011. Weed seedbanks in arable fields: effects of management practices and surrounding landscape: Weed seedbanks and agricultural intensity. Weed Research 51(6):631-640.

Kolb, L. N. and Gallandt, E. R. 2012. Weed management in organic cereals: advances and opportunities. Organic Agriculture 2(1):23-42.

Kouwenhoven, J. K. 1997. Intra-row mechanical weed control-possibilities and problems. Soil and Tillage Research 41(1-2):87-104. 
1 Kurstjens, D. A. G. and Kropff, M. J. 2001. The impact of uprooting and soil-covering on

22 the effectiveness of weed harrowing. Weed Research 41(3):211-228.

Kurstjens, D. A. G., Kropff, M. J., and Perdok, U. D. 2004. Method for predicting selective uprooting by mechanical weeders from plant anchorage forces. Weed Science 52(1):123-132.

Kurstjens, D. A. G., Perdok, U. D., and Goense, D. 2000. Selective uprooting by weed harrowing on sandy soils. Weed Research 40(5):431-447.

Laguë, C. and Khelifi, M. 2001. Energy use and time requirements for different weeding strategies in grain corn. Canadian Biosystems Engineering 43:213-221.

Lundkvist, A. 2009. Effects of pre- and post-emergence weed harrowing on annual weeds in peas and spring cereals. Weed Research 49(4):409-416.

Lyon, D. J., Blackshaw, R. E., and Gill, G. S. 2009. Cutting Down on Weeds to Cut a Cleaner Wheat Crop. Wheat Science and Trade Wiley-Blackwell. p. 251-272.

Meissle, M., Mouron, P., Musa, T., Bigler, F., Pons, X., Vasileiadis, V. P., Otto, S., Antichi, D., Kiss, J., Pálinkás, Z., Dorner, Z., Van Der Weide, R., Groten, J., Czembor, E., Adamczyk, J., Thibord, J.-B., Melander, B., Nielsen, G. C., Poulsen, R. T., Zimmermann, O., Verschwele, A., and Oldenburg, E. 2009. Pests, pesticide use and alternative options in European maize production: current status and future prospects: Pest management in European maize production. Journal of Applied Entomology 134(5):357-375.

Melander, B. 2014. Physical and cultural weed control - status and future directions. XXIX Brazilian Weed Science Conference Brazilian Weed Science Society, Gramado, Brazil. p. 1-9.

Melander, B., Rasmussen, I. A., and Bàrberi, P. 2005. Integrating physical and cultural methods of weed control-examples from European research. Weed Science 53(3):369-381. 
Moss, S. R. 2010. Integrated weed management (IWM): will it reduce herbicide use? Communications in Agricultural and Applied Biological Sciences 75(2):9-17.

Mulder, T. A. and Doll, J. D. 1993. Integrating Reduced Herbicide Use with Mechanical Weeding in Corn (Zea mays). Weed Technology 7(2):382-389.

Pannacci, E. and Tei, F. 2014. Effects of mechanical and chemical methods on weed control, weed seed rain and crop yield in maize, sunflower and soyabean. Crop Protection 64:51-59.

Piazza, C. 2004. Mais, coltivazioni in aumento. Inserto /Liste bio. ww.crpv.it [Internet]. Available at Website http://www.crpv.it/doc/5192/listamaisago04.pdf.

Pimentel, D., McLaughlin, L., Zepp, A., Lakitan, B., Kraus, T., Kleinman, P., Vancini, F., Roach, W. J., Graap, E., Keeton, W. S., and Selig, G. 1991. Environmental and Economic Effects of Reducing Pesticide Use. BioScience 41(6):402-409.

Rasmussen, J., Bibby, B. M., and Schou, A. P. 2008. Investigating the selectivity of weed harrowing with new methods. Weed Research 48(6):523-532.

Rasmussen, J., Kurtzmann, J. I., and Jensen, A. 2004. Tolerance of competitive spring barley cultivars to weed harrowing. Weed research 44(6):446-452.

Silva, P. S. L. E., Mesquita, S. S. X., ANTÔNIO, R. P., and SILVA, P. I. B. E. 2010. Number and time of weeding effects on maize grain yield. Revista Brasileira de Milho e Sorgo 3(02).

Sowinski, J., Kristensen, I. S., and Hermansen, J. E. 2002. A field study of maize yield on mixed organic and conventional dairy farms in Denmark in 2001. Scientific aspects of organic farming Latvia University of Agriculture, Jelgava.

Spagnolo, S., Pinna, M., Gamba, U., Zaccara, P., Possetto, D., and Valoti, P. 2005. Prova di coltivazione biologica di antichi mais piemontesi destinati all'alimentazione umana. BOLLETTINO DI AGRICOLTURA BIOLOGICA A CURA DEL CRAB (Reference Center for Organic Farming of Turin province) 2:47-57. 
Steinmann, H.-H. 2002. Impact of harrowing on the nitrogen dynamics of plants and soil. Soil and Tillage Research 65(1):53-59.

Tolera, A., Sundstøl, F., and Said, A. N. 1998. The effect of stage of maturity on yield and quality of maize grain and stover. Animal Feed Science and Technology 75(2):157-168.

Tollenaar, M., Dibo, A. A., Aguilara, A., Weise, S. F., and Swanton, C. J. 1994. Effect of crop density on weed interference in maize. Agronomy Journal 86(4):591-595.

Ulber, L., Steinmann, H.-H., Klimek, S., and Isselstein, J. 2009. An on-farm approach to investigate the impact of diversified crop rotations on weed species richness and composition in winter wheat. Weed Research 49(5):534-543.

Upadhyaya, M. K. and Blackshaw, R. E. (eds.). 2007a. Non-chemical weed management: principles, concepts and technology. CABI, Wallingford, UK; Cambridge, MA.

Upadhyaya, M. K. and Blackshaw, R. E. 2007b. Preface. In M. K. Upadhyaya and R. E. Blackshaw (eds.). Non-chemical weed management: principles, concepts and technology CABI, Wallingford, UK.

Van der Weide, R. Y., Bleeker, P. O., Achten, V., Lotz, L. A. P., Fogelberg, F., and Melander, B. 2008. Innovation in mechanical weed control in crop rows. Weed research 48(3):215-224.

Vanhala, P., Kurstjens, D., Ascard, J., Bertram, A., Cloutier, D. C., Mead, A., Raffaelli, M., and Rasmussen, J. 2004. Guidelines for physical weed control research: flame weeding, weed harrowing and intra-row cultivation. Proceedings 6th EWRS Workshop on Physical and Cultural Weed Control, 194-225 p. 194-225.

Vasileiadis, V. P., Otto, S., van Dijk, W., Urek, G., Leskovšek, R., Verschwele, A., Furlan, L., and Sattin, M. 2015. On-farm evaluation of integrated weed management tools for maize production in three different agro-environments in 
Vidotto, F., Fogliatto, S., Milan, M., and Ferrero, A. 2016. Weed communities in Italian maize fields as affected by pedo-climatic traits and sowing time. European Journal of Agronomy 74:38-46.

Vidotto, F., Tesio, F., Patracchini, C., Boni, A., and Ferrero, A. 2007. Evaluation of damage caused by spring tine harrowing in maize. European Weed Research Society-14th EWRS Symposium EWRS, Hamar, Norvegia. p. 81-81. 
Fogliatto 25

\section{Table captions}

22

3 Table 1. Weed density, weed reduction of STH over $\mathrm{CHK}$ and weed cover (\%) at each 4 weed assessment after mechanical treatments.

126 Table 2. Plant height of the maize cultivars in the different treatments in 2013 and $2014^{1}$.

${ }_{17}^{16} 8$ Table 3. Number of leaves per plant of the maize cultivars in the different treatments in

241 Table 4. Maize density (number of plants $\mathrm{m}^{-2}$ ) of the maize cultivars in the different 


\section{Figure captions}

${ }_{3}^{2} 2$ Figure 1: most represented weed species and Simpson and Shannon indices at the final 53 weed assessment ( 7 days after the third and fourth treatments in 2006 and 2007, ${ }_{8}^{7} 4$ respectively) in $\mathrm{CHK}$ and STH plots (percentage over total number of weeds found).

Figure 2. Yield, 1,000-seed weight, hectolitric weight and grain moisture at harvest in 2013 and 2014. Values sharing the same letter are not significantly different according to REGWF test $(P \leq 0.05)$. Lower case letters indicate comparison among treatments, while italics letters refer to comparison among varieties, averaging per treatments. Capital letters showed comparison among treatment within a variety and separately for each year. Yield, 1,000 -seed weight and hectolitric weight are standardized to $14 \%$ grain moisture. 
Table 1.

\begin{tabular}{|c|c|c|c|c|c|c|c|}
\hline \multirow{3}{*}{$\begin{array}{c}\text { Treatment } \\
\text { time }\end{array}$} & \multirow[b]{3}{*}{ Treatment } & \multirow{2}{*}{\multicolumn{3}{|c|}{2006}} & \multirow{2}{*}{\multicolumn{3}{|c|}{2007}} \\
\hline & & & & & & & \\
\hline & & $\begin{array}{c}\text { Weed } \\
\text { density } \\
\left(\text { plants } / \mathrm{m}^{2}\right)\end{array}$ & $\begin{array}{c}\text { Weed } \\
\text { reduction } \\
(\%)\end{array}$ & $\begin{array}{c}\text { Weed } \\
\text { Cover } \\
(\%)\end{array}$ & $\begin{array}{c}\text { Weed } \\
\text { density } \\
\left(\text { plants } / \mathrm{m}^{2}\right)\end{array}$ & $\begin{array}{c}\text { Weed } \\
\text { reduction } \\
(\%)\end{array}$ & $\begin{array}{c}\text { Weed } \\
\text { Cover } \\
(\%)\end{array}$ \\
\hline pre-treatments & - & 162.7 & - & 2.3 & 304.0 & - & 5.8 \\
\hline \multirow[t]{2}{*}{ post- $1^{\text {st }}$ treatment } & $\mathrm{CHK}$ & $137.0^{*}$ & 51.8 & 7.9 & $467.5^{*}$ & 30.5 & 25.1 \\
\hline & STH & 66.0 & - & 4.6 & 325.0 & - & 30.7 \\
\hline \multirow[t]{2}{*}{ post- $2^{\text {nd }}$ treatment } & $\mathrm{CHK}$ & $124.5^{*}$ & 73.2 & 41.8 & $437.3^{*}$ & 27.5 & 41.3 \\
\hline & STH & 33.4 & - & 18.0 & 317.1 & & 35.2 \\
\hline \multirow[t]{2}{*}{ post- $3^{\text {rd }}$ treatment } & $\mathrm{CHK}$ & $86.7^{*}$ & 38.7 & 99.6 & $277.7^{*}$ & 64.8 & 58.5 \\
\hline & STH & 53.1 & - & 78.4 & 97.8 & - & 21.9 \\
\hline \multirow[t]{2}{*}{ post $-4^{\text {th }}$ treatment } & $\mathrm{CHK}$ & - & - & & $241.1^{*}$ & 78.5 & 92.5 \\
\hline & STH & - & - & & 51.9 & - & 22.5 \\
\hline
\end{tabular}

*: significant comparison between $\mathrm{CHK}$ and STH for each treatment time. 
Table 2.

\begin{tabular}{|c|c|c|c|c|c|c|c|c|c|c|c|}
\hline \multirow[b]{2}{*}{ Variety } & \multirow{2}{*}{ 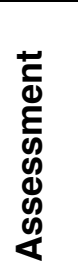 } & \multicolumn{5}{|c|}{2013} & \multicolumn{5}{|c|}{2014} \\
\hline & & CHK & STH & MWR & $\begin{array}{l}\text { STH+ } \\
\text { MWR }\end{array}$ & Average & CHK & STH & MWR & $\begin{array}{l}\text { STH+ } \\
\text { MWR }\end{array}$ & Average \\
\hline \multirow[t]{4}{*}{ Maranello } & $1^{\text {st }}$ & 22.9 & 22.5 & 21.8 & 22.3 & 22.5 & 29.0 & 29.5 & 30.7 & 28.7 & $29.5 a$ \\
\hline & $2^{\text {nd }}$ & 30.4 & 28.2 & 30.1 & 30.8 & 29.9 & 33.9 & 33.9 & 36.1 & 38.9 & $35.7 a b$ \\
\hline & $3^{\text {rd }}$ & 39.7 & 42.1 & 40.5 & 40.6 & 40.7 & 51.9 & 56.2 & 51.6 & 55.2 & 53.7 \\
\hline & $4^{\text {th }}$ & 72.5 & 75.9 & 67.9 & 69.1 & 71.3ab ${ }^{1}$ & 67.5 & 68.9 & 67.9 & 72.4 & $69.2 a$ \\
\hline \multirow[t]{4}{*}{ Marano } & $1^{\text {st }}$ & 21.1 & 22.6 & 22.2 & 20.1 & 21.3 & 23.4 & 30.0 & 33.5 & 29.2 & $30.5 a$ \\
\hline & $2^{\text {nd }}$ & 29.5 & 31.3 & 30.3 & 29.4 & 32.2 & 31.0 & 35.9 & 37.1 & 37.4 & 35.3ab \\
\hline & $3^{\text {rd }}$ & 39.6 & 43.9 & 39.3 & 36.3 & 39.8 & 54.8 & 54.6 & 58.1 & 54.8 & 55.6 \\
\hline & $4^{\text {th }}$ & 61.5 & 72.0 & 69.5 & 59.7 & $65.7 a b$ & 70.0 & 67.7 & 81.3 & 66.9 & 71.5ab \\
\hline \multirow[t]{4}{*}{ Nostrano } & $1^{\text {st }}$ & 22.9 & 24.3 & 23.7 & 23.9 & 23.7 & 34.3 & 33.5 & 35.0 & 32.8 & $33.9 b$ \\
\hline & $2^{\text {nd }}$ & 26.4 & 33.9 & 32.7 & 35.7 & 30.1 & 36.5 & 41.0 & 39.5 & 37.2 & $38.6 b$ \\
\hline & $3^{\text {rd }}$ & 44.0 & 42.4 & 45.3 & 43.8 & 43.9 & 62.2 & 58.4 & 56.2 & 58.7 & 58.9 \\
\hline & $4^{\text {th }}$ & 65.9 & 73.1 & 75.7 & 73.3 & $72.0 \mathrm{~b}$ & 79.7 & 73.4 & 79.4 & 75.3 & $77.0 \mathrm{~b}$ \\
\hline \multirow[t]{4}{*}{ Ottofile } & $1^{\text {st }}$ & 24.7 & 19.8 & 24.1 & 20.2 & 21.8 & 30.0 & 32.7 & 29.5 & 33.5 & $30.2 a$ \\
\hline & $2^{\text {nd }}$ & 26.1 & 26.6 & 29.3 & 26.3 & 27.1 & 32.6 & 34.3 & 33.3 & 41.0 & $32.9 a$ \\
\hline & $3^{\text {rd }}$ & 41.3 & 40.0 & 40.7 & 43.7 & 41.4 & 55.9 & 57.0 & 52.5 & 58.4 & 55.0 \\
\hline & $4^{\text {th }}$ & 76.6 & 70.4 & 66.8 & 74.4 & $72.1 b$ & 69.7 & 75.4 & 71.5 & 73.4 & 72.2ab \\
\hline \multirow[t]{4}{*}{ Pignoletto } & $1^{\text {st }}$ & 22.1 & 23.4 & 23.4 & 21.2 & 22.3 & 27.8 & 31.4 & 28.3 & 28.3 & $28.9 a$ \\
\hline & $2^{\text {nd }}$ & 25.0 & 28.4 & 31.9 & 28.0 & 28.3 & 34.4 & 36.7 & 35.7 & 35.7 & $35.7 a b$ \\
\hline & $3^{\text {rd }}$ & 41.9 & 37.8 & 38.1 & 36.8 & 38.7 & 53.1 & 57.6 & 52.2 & 52.2 & 55.3 \\
\hline & $4^{\text {th }}$ & 65.4 & 68.5 & 67.4 & 54.1 & $63.9 a$ & 71.2 & 71.4 & 68.9 & 68.9 & 70.4ab \\
\hline
\end{tabular}


${ }^{1}$ Values within each column sharing the same letter are not significantly different according to REGWF test $(P \leq 0.05)$. When no letters are shown, the values are not significantly different. Comparisons were made between maize varieties separately for each assessment and separately for each year. 
Table 3.

\begin{tabular}{|c|c|c|c|c|c|c|c|c|c|c|c|}
\hline \multirow[b]{2}{*}{ Variety } & \multirow{2}{*}{ 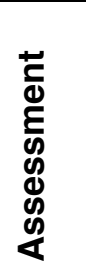 } & \multicolumn{5}{|c|}{2013} & \multicolumn{5}{|c|}{2014} \\
\hline & & CHK & STH & MWR & $\begin{array}{l}\text { STH+ } \\
\text { MWR }\end{array}$ & Average & CHK & STH & MWR & $\begin{array}{l}\text { STH+ } \\
\text { MWR }\end{array}$ & Average \\
\hline \multirow[t]{4}{*}{ Maranello } & $1^{\text {st }}$ & 3.4 & 3.5 & 3.6 & 3.4 & $3.4 b$ & 5.3 & 5.5 & 5.1 & 5.6 & $5.4 a$ \\
\hline & $2^{\text {nd }}$ & 4.7 & 4.7 & 4.7 & 4.9 & 4.7 & 6.1 & 6.2 & 6.1 & 6.3 & 6.2 \\
\hline & $3^{\text {rd }}$ & 7.5 & 7.5 & 7.5 & 7.4 & 7.5 & 8.0 & 7.3 & 8.2 & 8.4 & 8.0 \\
\hline & $4^{\text {th }}$ & 9.1 & 10.1 & 10.0 & 9.5 & $9.7 a$ & $8.6 a$ & $9.2 b$ & $9.9 c$ & $9.6 c$ & $9.3 a$ \\
\hline \multirow[t]{4}{*}{ Marano } & $1^{\text {st }}$ & 3.1 & 3.3 & 3.5 & 3.1 & $3.2 a$ & 5.1 & 5.4 & 5.1 & 5.3 & $5.2 a$ \\
\hline & $2^{\text {nd }}$ & 4.8 & 5.0 & 4.5 & 4.7 & 4.8 & 5.8 & 6.2 & 6.1 & 6.0 & 6.0 \\
\hline & $3^{\text {rd }}$ & 8.1 & 8.0 & 8.6 & 7.6 & 8.1 & 8.0 & 7.9 & 8.3 & 8.0 & 8.1 \\
\hline & $4^{\text {th }}$ & $8.3 a$ & $10.3 b$ & $10.4 b$ & $9.7 a b$ & $9.7 a$ & $9.4 a$ & $9.2 a$ & $10.1 b$ & $8.9 a$ & $9.4 a$ \\
\hline \multirow[t]{4}{*}{ Nostrano } & $1^{\text {st }}$ & 3.3 & 3.4 & 3.5 & 3.3 & $3.3 a b$ & 5.5 & 5.4 & 5.1 & 5.5 & $5.4 a$ \\
\hline & $2^{\text {nd }}$ & 5.0 & 4.9 & 4.9 & 5.0 & 4.9 & 6.3 & 6.4 & 6.2 & 6.4 & 6.3 \\
\hline & $3^{\text {rd }}$ & 7.1 & 8.1 & 7.9 & 8.0 & 7.8 & 8.3 & 7.9 & 8.8 & 8.6 & 8.4 \\
\hline & $4^{\text {th }}$ & $9.4 a$ & $11.0 b$ & $10.8 b$ & $11.7 b$ & $10.7 b$ & 10.1 & 9.9 & 10.8 & 10.5 & $10.3 c$ \\
\hline \multirow[t]{4}{*}{ Ottofile } & $1^{\text {st }}$ & 3.2 & 3.2 & 3.4 & 3.1 & $3.2 \mathrm{ab}$ & 5.2 & 5.2 & 5.3 & 5.2 & $5.3 a$ \\
\hline & $2^{\text {nd }}$ & 4.2 & 4.3 & 4.7 & 4.7 & 4.5 & 6.2 & 6.1 & 6.3 & 6.0 & 6.2 \\
\hline & $3^{\text {rd }}$ & 7.3 & 7.9 & 7.8 & 7.7 & 7.7 & 7.7 & 8.1 & 8.4 & 8.1 & 8.1 \\
\hline & $4^{\text {th }}$ & 9.2 & 9.7 & 9.4 & 10.7 & $9.8 a$ & $9.1 a$ & $9.9 a b$ & $10.5 b$ & $9.8 a b$ & $9.8 b$ \\
\hline \multirow[t]{4}{*}{ Pignoletto } & $1^{\text {st }}$ & 3.4 & 3.4 & 3.5 & 3.4 & $3.4 b$ & $5.4 a$ & $6.0 b$ & $5.7 a b$ & $6.0 b$ & $5.8 b$ \\
\hline & $2^{\text {nd }}$ & 4.8 & 4.8 & 5.2 & 4.6 & 4.8 & 6.5 & 6.5 & 6.4 & 6.0 & 6.4 \\
\hline & $3^{\text {rd }}$ & 8.0 & 8.1 & 8.2 & 8.3 & 9.5 & 8.2 & 8.3 & 8.6 & 8.4 & 8.4 \\
\hline & $4^{\text {th }}$ & 9.4 & 10.3 & 10.9 & 9.7 & $10.1 a b$ & 10.0 & 10.2 & 10.5 & 10.3 & $10.3 c$ \\
\hline
\end{tabular}




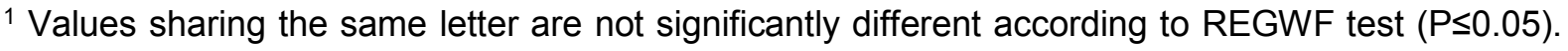
When no letters are shown, the values are not significantly different. Comparisons were made between maize varieties separately for each assessment and separately for each year. Italic letters indicate the comparison among treatments within the same assessment for each variety, separately for each year. 
Table 4.

\begin{tabular}{|c|c|c|c|c|c|c|c|c|c|c|c|}
\hline \multirow[b]{2}{*}{ Variety } & \multirow{2}{*}{ 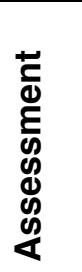 } & \multicolumn{5}{|c|}{2013} & \multicolumn{5}{|c|}{2014} \\
\hline & & CHK & STH & MWR & $\begin{array}{l}\text { STH+ } \\
\text { MWR }\end{array}$ & Average & CHK & STH & MWR & $\begin{array}{l}\text { STH+ } \\
\text { MWR }\end{array}$ & Average \\
\hline \multirow[t]{4}{*}{ Maranello } & $1^{\text {st }}$ & 5.2 & 5.5 & 5.4 & 5.0 & $5.3 d$ & 5.5 & 5.5 & 6.0 & 6.2 & 5.8 \\
\hline & $2^{\text {nd }}$ & 4.9 & 4.5 & 5.6 & 4.5 & $4.9 b$ & 5.5 & 5.8 & 5.8 & 6.2 & 5.9 \\
\hline & $3^{\text {rd }}$ & 4.9 & 4.8 & 5.2 & 5.0 & $5.0 \mathrm{~b}$ & 5.6 & 5.9 & 6.1 & 6.1 & $6.0 \mathrm{~b}$ \\
\hline & $4^{\text {th }}$ & 4.9 & 5.4 & 5.7 & 5.2 & 5.3 & 5.5 & 5.8 & 6.2 & 6.0 & 5.8 \\
\hline \multirow[t]{4}{*}{ Marano } & $1^{\text {st }}$ & 4.5 & 3.6 & 4.3 & 4.7 & $4.2 a$ & 5.3 & 5.5 & 5.3 & 5.6 & 5.4 \\
\hline & $2^{\text {nd }}$ & 4.6 & 3.7 & 4.0 & 4.4 & $4.1 \mathrm{a}$ & 5.3 & 5.7 & 5.5 & 5.6 & 5.5 \\
\hline & $3^{\text {rd }}$ & 4.1 & 3.8 & 3.5 & 4.1 & $3.9 a$ & 5.3 & 5.7 & 5.6 & 5.5 & $5.5 a b$ \\
\hline & $4^{\text {th }}$ & 5.4 & 4.5 & 4.1 & 4.5 & 4.6 & 5.4 & 5.6 & 5.6 & 5.6 & 5.5 \\
\hline \multirow[t]{4}{*}{ Nostrano } & $1^{\text {st }}$ & 4.6 & 4.2 & 4.3 & 4.4 & $4.4 a b$ & 5.8 & 5.8 & 5.5 & 6.0 & 5.8 \\
\hline & $2^{\text {nd }}$ & 4.2 & 4.7 & 4.2 & 4.4 & $4.4 a b$ & 5.8 & 6.3 & 5.5 & 6.1 & 5.9 \\
\hline & $3^{\text {rd }}$ & 4.1 & 3.9 & 4.0 & 3.5 & $3.9 a$ & 5.5 & 6.0 & 5.6 & 5.9 & $5.7 a b$ \\
\hline & $4^{\text {th }}$ & 4.7 & 5.0 & 4.4 & 5.2 & 4.8 & 5.5 & 5.5 & 5.6 & 6.1 & 5.7 \\
\hline \multirow[t]{4}{*}{ Ottofile } & $1^{\text {st }}$ & 5.5 & 5.1 & 5.0 & 5.1 & $5.2 \mathrm{~cd}$ & 5.8 & 5.6 & 5.6 & 5.6 & 5.7 \\
\hline & $2^{\text {nd }}$ & 4.2 & 4.7 & 5.1 & 4.2 & $4.5 a b$ & 6.1 & 5.8 & 5.5 & 5.8 & 5.8 \\
\hline & $3^{\text {rd }}$ & 4.7 & 4.9 & 4.7 & 3.8 & $4.5 a b$ & 5.8 & 6.1 & 5.6 & 5.8 & $5.8 a b$ \\
\hline & $4^{\text {th }}$ & 4.1 & 5.1 & 5.6 & 5.0 & 5.0 & 5.7 & 5.8 & 5.7 & 5.8 & 5.8 \\
\hline \multirow[t]{4}{*}{ Pignoletto } & $1^{\text {st }}$ & 4.7 & 4.8 & 4.8 & 4.7 & $4.8 \mathrm{bc}$ & 5.7 & 5.8 & 5.7 & 5.6 & 5.7 \\
\hline & $2^{\text {nd }}$ & 4.5 & 5.0 & 5.1 & 4.8 & $4.8 b$ & 5.3 & 5.6 & 5.7 & 5.7 & 5.6 \\
\hline & $3^{\text {rd }}$ & 4.4 & 4.2 & 5.0 & 4.1 & $4.4 a b$ & 5.3 & 5.5 & 5.8 & 5.5 & $5.5 a$ \\
\hline & $4^{\text {th }}$ & 4.0 & 5.8 & 4.5 & 4.9 & 4.8 & 5.4 & 5.5 & 5.8 & 5.6 & 5.6 \\
\hline
\end{tabular}


${ }^{1}$ Values sharing the same letter are not significantly different according to REGWF test $(P \leq 0.05)$. When no letters are shown, the values are not significantly different. Comparisons were made between maize varieties separately for each assessment and separately for each year. 
Figure1

\section{CHK}

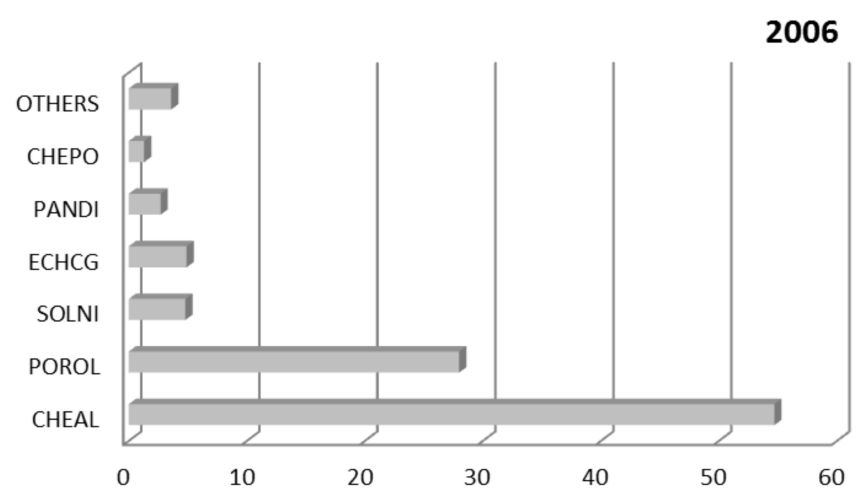

Simpson index (D): 0.38 Shannon index $\left(\mathrm{H}^{\prime}\right): 1.33$

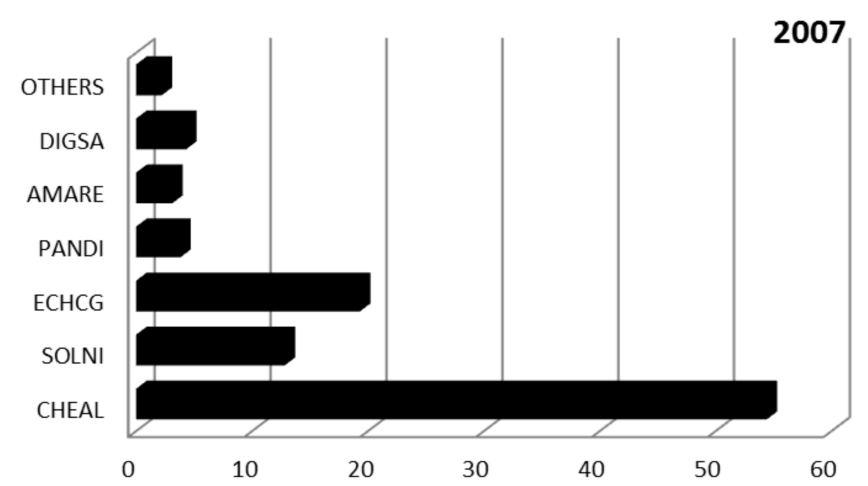

Simpson index (D): 0.35 Shannon index $\left(\mathrm{H}^{\prime}\right): 1.40$

\section{STH}

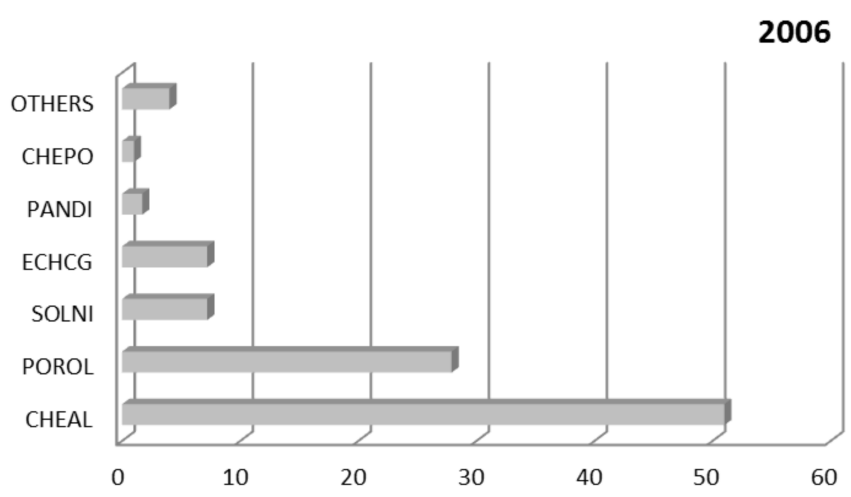

Simpson index (D): 0.35 Shannon index $\left(\mathrm{H}^{\prime}\right): 1.35$

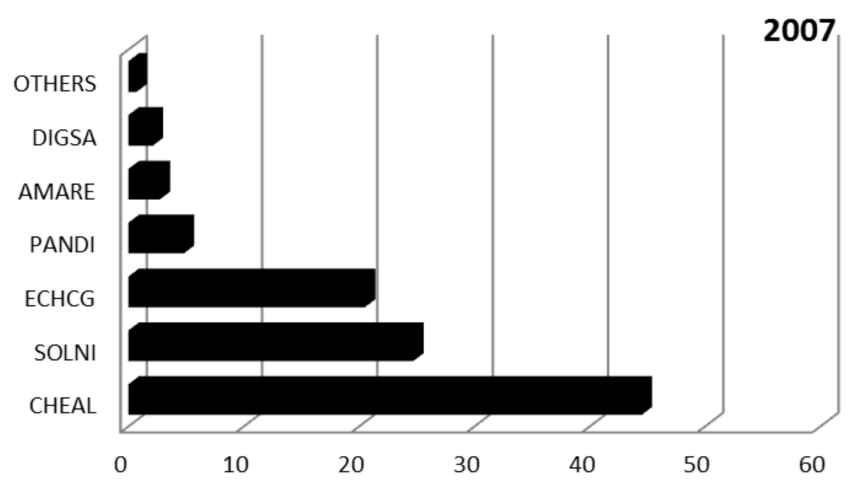

Simpson index (D): 0.30 Shannon index $\left(\mathrm{H}^{\prime}\right): 1.39$ 
Figure2

\section{3}
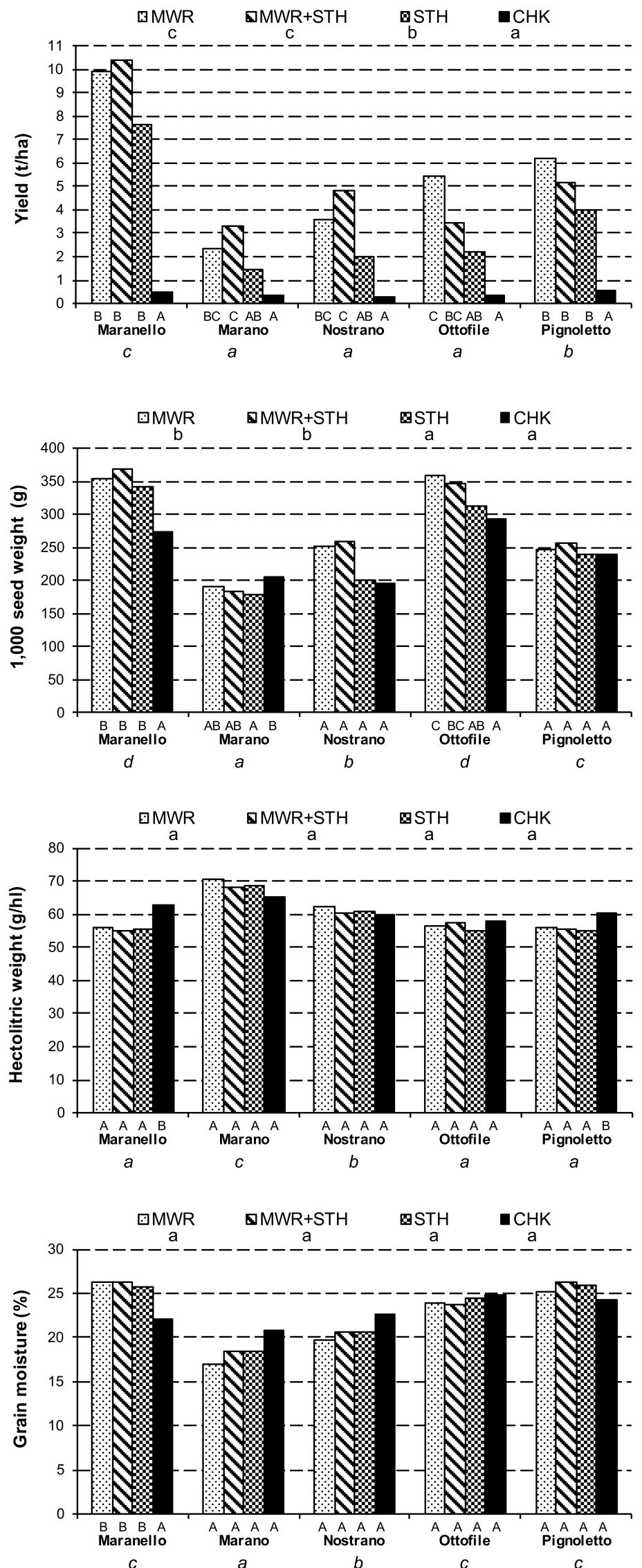

2014
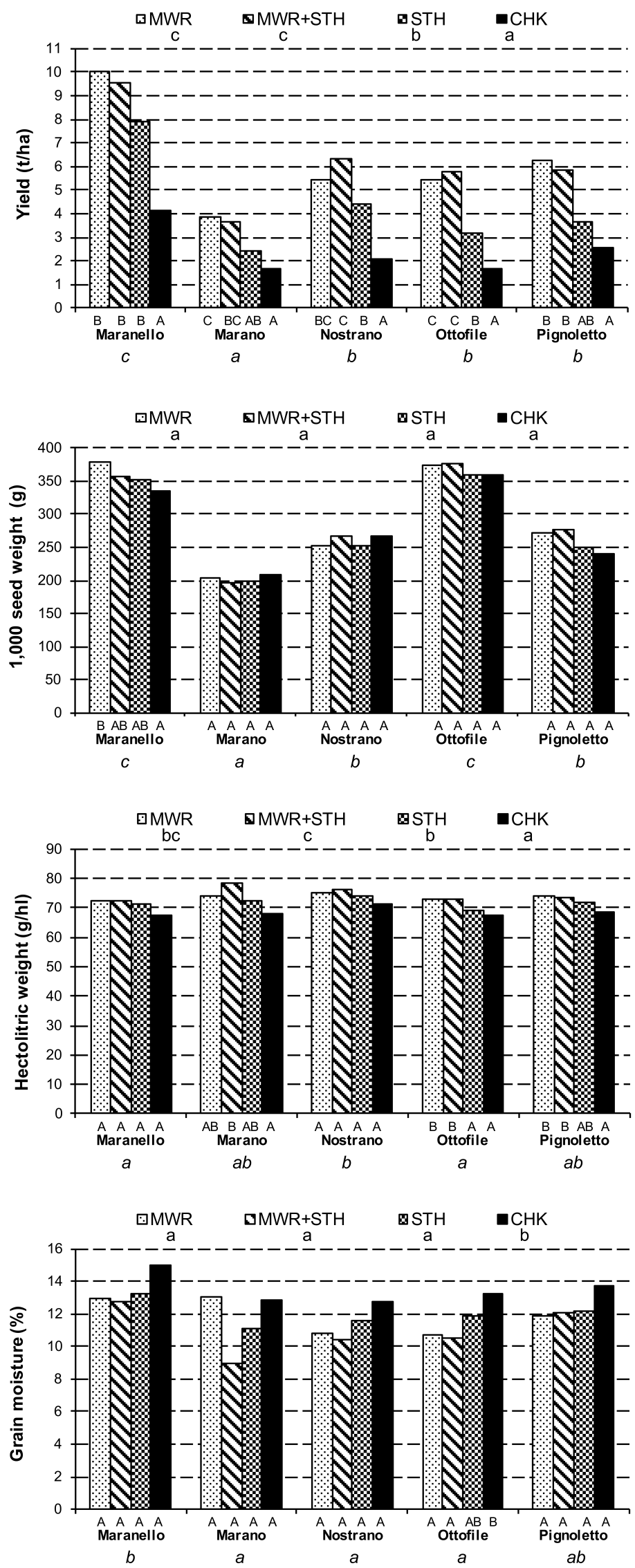